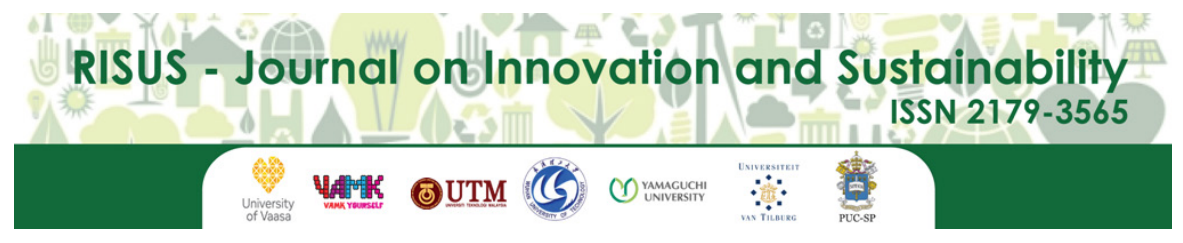

\title{
NATIONAL CULTURE AND TRANSPARENCY: EVIDENCE FROM ISLAMIC BANKS
}

Cultura nacional e transparência:

Evidências dos bancos Islâmicos

\author{
Rochania Ayu Yunanda, Mohammad Ali Tareq, Akbariah Binti Mahdzir, \\ Faried Kurnia Rahman \\ Management of Technology, MJIIT, University Tecnology, Malaysia \\ E-mail: anda1st@gmail.com, tareq@utm.my, akbariah.k1@utm.my, \\ fariedkr@gmail.com
}

\begin{abstract}
The purpose of this paper is to investigate the effects of predominant cultural values on banking disclosure. On one hand, Islamic banks have practiced Islamic principles which are universal for all countries. Islamic banks are expected to provide transparent information especially in terms of social and Shariah(Islamic) compliant information as Islamic banks claim themselves to have social objectives as the prime consideration. Islamic banks also have Shariah supervisory body to ensure that the banking activities and business operations are in line with Islamic requirements. On the other hand, Hofstede's cultural dimensions and Gray's hypotheses have rendered remarkable contributions in financial and accounting practices among different nations. Examining 45 Islamic banks in 11 Moslem majority countries, this paper focuses on four particular cultural dimensions namely individualism/collectivism, masculinity/femininity, uncertainty avoidance, and power distance and whether these dimensions have an impact on transparency. This study found that two out of four national cultures still have significant effect on the transparency level in Moslem majority countries. Key words: Cultural values; Shariah disclosure; Social disclosure; Islamic banks
\end{abstract}




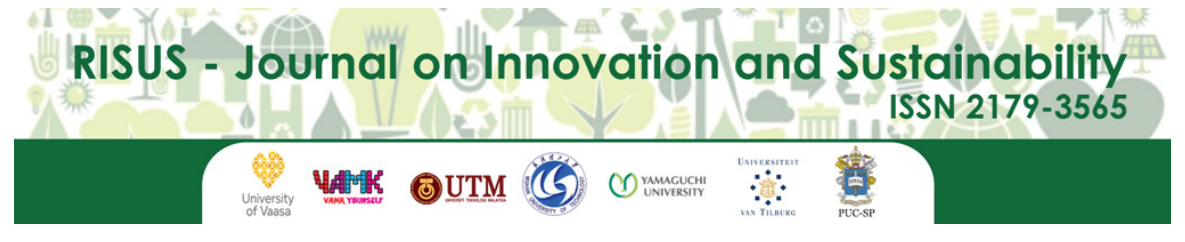

RISUS - Journal on Innovation and Sustainability volume 10, número 1 - 2019

ISSN: $2179-3565$

Editor Científico: Arnoldo José de Hoyos Guevara Editora Assistente: Lívia Lopes Aguiar Avaliação: Melhores práticas editoriais da ANPAD

\title{
NATIONAL CULTURE AND TRANSPARENCY: EVIDENCE FROM ISLAMIC BANKS
}

Cultura nacional e transparência:

Evidências dos bancos Islâmicos

\begin{abstract}
Rochania Ayu Yunanda, Mohammad Ali Tareq, Akbariah Binti Mahdzir, Faried Kurnia Rahman Management of Technology, MJIIT, University Tecnology, Malaysia E-mail: anda1st@gmail.com, tareq@utm.my, akbariah.kl@utm.my, fariedkr@gmail.com
\end{abstract}

Resumo: O objetivo deste trabalho é investigar os efeitos de valores culturais predominantes na divulgação bancária. Por um lado, os bancos islâmicos praticaram princípios islâmicos que são universais para todos os países. Espera-se que os bancos islâmicos forneçam informações transparentes, especialmente em termos de informações sociais e da Shariah (islâmica), uma vez que os bancos islâmicos afirmam ter objetivos sociais como a principal consideração. Os bancos islâmicos também têm o órgão de supervisão da Sharia para garantir que as atividades bancárias e as operações de negócios estejam de acordo com os requisitos islâmicos. Por outro lado, as dimensões culturais de Hofstede e as hipóteses de Gray renderam contribuições notáveis em práticas financeiras e contábeis entre diferentes nações. Examinando 45 bancos islâmicos em 11 países de maioria muçulmana, este artigo enfoca quatro dimensões culturais específicas, a saber, individualismo / coletivismo, masculinidade / feminilidade, evitação de incertezas e distância do poder e se essas dimensões têm impacto na transparência. Este estudo descobriu que duas das quatro culturas nacionais ainda têm efeito significativo sobre o nível de transparência nos países de maioria muçulmana.

Palavras-Chave: Valores Culturais; Divulgação da Sharia; Divulgação social; Bancos Islâmicos

\author{
RECEBIDO EM: 12/05/2018 \\ ACEITO EM: 01/03/2019
}




\section{INTRODUCTION}

Each accounting system is a product of its specific culture and environment(Askary, Pounder, azdifar, 2008). The nature of accounting as social science makes it inseparable from environmental influence, social values, culture and also religion. Gray's paper in 1988 was a pioneering paper contributing the idea that culture might affect accounting practice (Chanchani and Willett, 2004). Gray proposed some hypotheses derived from Hofstede's societal values (Chanchani and Willett, 2004; Hofstede, 1991). Gray came up with four significant accounting value dimensions derived from accounting literature were offered, encompassing professionalism versus statutory control, uniformity versus flexibility, conservatism versus optimism, and secrecy versus transparency (Gray, 1988). Integrated with Hofstede's societal values, these accounting dimensions have been used to propose cultural areas categorizing the countries which can be grouped into areas on the basis of cultural characteristics. However, this study focuses on one accounting value dimension which is transparency. As Gray(1988) hypothesized that a country with higher uncertainty avoidance and power distance and lower level of individualism and masculinity tends to have higher level of secrecy.

Not many studies have been conducted in the scope of the influence of cultural dimensions in Islamic banks. Islamic banks are unique. Islamic banks are created based on the principles clearly mentioned in the Quran (Wan Ibrahim and Ismail, 2015). Social objectives of Islamic banks can be accessed through the disclosure of zakah, qardhhassan, charity, other social activities in the annual reports(Ali and Hasan, 2014; Aribi and Gao, 2012; Hassan and Harahap, 2010) and also profit sharing contracts as the implementation of no interest business (Asutay and Harningtyas, 2015; Ghayad, 2008;

Rosly, Afandi, \& Bakar, 2003; Zarrouk, Jedidia, and Moualhi, 2016). This unique system of Islamic banks is universally practicable in all Islamic banks in the world regardless cultural differences.

The paper proceeds as follows. The first section provides literature on Hofstede's cultural dimensions being widely used in cross-cultural studies in accounting. This section then goes on to explore Gray's first work. The next section provides insight into profit sharing system. The next section explains the hypothesis of the study. The following section discusses the research methodology followed by analysis and discussion. The last section concludes the study.

\section{LITERATURE REVIEW}

\section{Hofstede's Cultural Dimensions and Gray's hypotheses}

Culture is often defined as a system of shared attitudes, values, and beliefs that characterizes individual or group perceptions, preferences, and behaviours (Anderson, Fedenia, Hirschey, Skiba, 2011) and influences all aspects of a society's and an individual's life (Gaygisiz, 2013). The impact of culture on has been carried out in many different studies. Studying the cultural impacts on accounting has become popular since Gray initiated his work in the late 1980s. He offered a contribution towards a theory of cultural influence on the development of accounting systems internationally.

Gray's hypotheses were based on four cultural dimensions. This study examines three out of six

Hofstede's dimensions; Large versus Small Power Distance, Individualism versus Collectivism, and Strong versus Weak Uncertainty Avoidance. It excludes Masculinity versus Femininity, Long Term

Orientation versus Short Term Normative Orientation and Indulgence versus Restrain. Power distance can therefore be defined as the extent to which the less powerful members of institutions and organizations within a country expect and accept that power is distributed unequally (Hofstede, 1991). As such, high power distance societies accept the unequal distribution of power and authority (Boubakri, Mirzaei, Samet, 2017). Hofstede defines individualism as a dimension pertaining to societies in which the ties between individuals are loose; everyone is expected to look after himself or herself and his or her immediate family. Uncertainty avoidance is defined as the extent to which the members of a culture feel threatened by uncertain or unknown situation (Boubakri et al., 2017; Laitinen and Suvas, 2016). In countries with strong uncertainty avoidance there tend to be more and more precise rules and laws than in those with weak uncertainty avoidance in which in a condition when rules and laws cannot be respected, they should be changed.

Gray's work in 1988 was a pioneering paper contributing the idea that culture might affect accounting practice (Chanchani and Willett, 2004). Gray proposed some hypotheses derived from

Hofstede's cultural values. Gray proposed four hypotheses developed from Hofstede's cultural 
values combined with four significant accounting values encompassing professionalism versus statutory control, uniformity versus flexibility, conservatism versus optimism, and secrecy versus transparency (Chanchani and Willett, 2004; Gray, 1983). However, this study mainly examine one out of four Gray's hypotheses stating that a country with higher uncertainty avoidance and power distance and lower level of individualism and masculinity tends to have higher level of secrecy.

\section{Transparency through Islamic Banking Disclosure}

Corporate disclosures relates to social and moral values. It can be said that this service is more related to Islamic banks (Abbasi et al., 2012). Islamic banks have the objective to uphold ethical financial system (Asutay and Harningtyas, 2015) with the final objective to promote the prosperity (Bukhari, Awan, Ahmed, 2013) both economic and social welfare(Dusuki, 2008). Islamic banks must also ensure the conformance with Shariah principles and requirements. Having more social responsibilities, Islamic banks are expected to involve more social activities. Islamic banks have the responsibility in terms of charity and Islamic charity called zakah and qard(Maali, Casson, Napier, 2006;

Nobanee and Ellili, 2016). Therefore, Islamic banks should have broader and more comprehensive disclosure (Haniffa and Hudaib, 2007).

\section{HYPOTHESIS}

This study aims to test one of Gray's hypotheses stating that a country with higher uncertainty avoidance and power distance and lower level of individualism and masculinity tends to have higher level of secrecy. However, Islamic banks have to disclose the similar information on zakah (obligatory charity), qardhhassan(benevolence loans), charity, other social activities in the annual reports (Ali and

Hasan, 2014; Aribi and Gao, 2012; Hassan and Harahap, 2010) and also profit sharing contracts as the implementation of no interest business (Asutay and Harningtyas, 2015; Zarrouk et al., 2016). This should be commonly practiced in all Islamic banks in different nations regardless cultural dissimilarities.

Therefore, this study hypothesizes that uncertainty avoidance, power distance, individualism and masculinity do not have impact on transparency level (disclosure).

Ho: There is no significant impact of cultural differences (uncertainty avoidance, power distance, individualism and masculinity) on transparency level (disclosure) in Islamic banks in different countries.

Ha: There is asignificant impact of cultural differences (uncertainty avoidance, power distance, individualism and masculinity) on transparency level (disclosure) in Islamic banks in different countries.

\section{RESEARCH METHODOLOGY}

This is a quantitative research because its objective is to empirically examine the relationship and causality of several variables. The purpose of quantitative research is to test the hypotheses or make some predictions(Cooper and Schindler, 2011). This study examines the latest 45 Islamic banks ${ }^{6}$ annual reports in eleven countries year of 2015. Numerous studies have utilized the published annual reports which are considered as the main source of information for the stakeholders(Lu and Abeysekera, 2014; Soana, 2011). The data will be analysed using regression. 
Table 1. Measurements of the Variables

\begin{tabular}{|c|c|c|}
\hline MAIN VARIABLES & VARIABLES & MEASUREMENT \\
\hline \multicolumn{3}{|l|}{ DEPENDENT: } \\
\hline \multirow[t]{2}{*}{ DISCLOSURE } & Disclosure & $\begin{array}{l}\text { Disclosure index based on the } \\
\text { proposed disclosure categorization }\end{array}$ \\
\hline & & $\begin{array}{l}\text { including social and Shariah } \\
\text { compliance disclosures }\end{array}$ \\
\hline \multicolumn{3}{|l|}{ INDEPENDENT: } \\
\hline MOSLEM POPULATION & $\begin{array}{l}\text { Shariah Supervisory Board } \\
\text { Muslim population }\end{array}$ & $\begin{array}{l}\text { SSB size } \\
\text { The percentage of muslim } \\
\text { population in the country }\end{array}$ \\
\hline \multirow[b]{2}{*}{ COUNTRY VALUE } & $\begin{array}{l}\text { Individualism } \\
\text { Masculinity } \\
\text { Power Distance }\end{array}$ & $\begin{array}{l}\text { Individualism index based on } \\
\text { country ranks (Hofstede, 1983; } \\
\text { Gray, 1988) } \\
\text { Maculinity index based on country } \\
\text { ranks (Hofstede, 1983; Gray, 1988) }\end{array}$ \\
\hline & Uncertainty Avoidance & $\begin{array}{l}\text { Power distance index based on } \\
\text { country ranks (Hofstede, 1983; } \\
\text { Gray, 1988) } \\
\text { Uncertainty avoidance index based } \\
\text { on country ranks (Hofstede, 1983; } \\
\text { Gray, 1988) }\end{array}$ \\
\hline
\end{tabular}

The model specification is as follow:

Explanation:

$$
D I S C=M O S L+S S B+P D+U A+M A S+I N D+e
$$

DISC $=$ Shariah and Social Disclosure

MOSL $=$ Moslem Population

SSB $=$ Shariah Supervisory Board Score

IND= Individualism

MAS $=$ Masculinity

PD $=$ Power Distance

$\mathrm{UA}=$ Uncertainty Avoidance

$\mathrm{e}=$ Error

\section{ANALYSIS AND DISCUSSION}

This section discusses the data analysis and the results.

Table 2 Descriptive Statistics

\begin{tabular}{lcccccc}
\hline & $\begin{array}{c}\text { Power } \\
\text { Distance }\end{array}$ & Individualism & $\begin{array}{c}\text { Uncertainty } \\
\text { Avoidance }\end{array}$ & $\begin{array}{c}\text { Moslem } \\
\text { Population }\end{array}$ & $\begin{array}{c}\text { Shariah } \\
\text { Supervisory } \\
\text { Board }\end{array}$ & $\begin{array}{c}\text { Social } \\
\text { \&Shariah } \\
\text { Disclosures }\end{array}$ \\
\hline $\mathrm{N} \quad$ Valid & 45 & 45 & 45 & 45 & 45 & 45 \\
Mean & 0 & 0 & 0 & 0 & 0 & 0 \\
Median & 79.9556 & 28.1778 & 58.2667 & 84.0533 & 3.2222 & 44.6667 \\
Skewness & 80.0000 & 26.0000 & 60.0000 & 86.4000 & 3.0000 & 43.0000 \\
Kurtosis & .122 & -.231 & -.573 & -.805 & .033 & .454 \\
Minimum & .026 & -1.653 & -.784 & -.329 & -.388 & -.677 \\
Maximum & 55.00 & 14.00 & 36.00 & 61.40 & 0.00 & 13.00 \\
\hline
\end{tabular}


The assumption of normality is measured by Skewness and Kurtosis. The value of Skewness and Kurtosis should range between +1 to -3 . The value of Skewness and Kurtosis close to zero indicates that the distribution is symmetric(Cooper and Schindler, 2011). All the data have Skewness and Kurtosis values between the ranges. The data do not have multicollinearity as well which are concluded from VIF and Tolerance values. Variance inflation factors (VIF) are less than 10 for all variables. Tolerance values are all below 0.1 . Overall, it indicates that multicollinearity is unlikely to be a problem (See table 4.4).

Table 3 Model Summary

\begin{tabular}{ccccc}
\hline Model & R & R Square & Adjusted R Square & $\begin{array}{c}\text { Std. Error of the } \\
\text { Estimate }\end{array}$ \\
\hline 1 & $.667^{2}$ & .444 & .357 & 16.65404 \\
\hline
\end{tabular}

a. Predictors: (Constant), Shariah Supervisory Board, Individualism, Uncertainty Avoidance, Moslem Population, Power Distance, Masculinity

Table 4 The Significance of the Model

\begin{tabular}{llccccc}
\hline \multicolumn{1}{r}{ Model } & $\begin{array}{c}\text { Sum of } \\
\text { Squares }\end{array}$ & df & Mean Square & F & \multirow{2}{*}{ Sig. } \\
\hline \multirow{3}{*}{1} & Regression & 7267.224 & 5 & 1453.445 & 5.064 & .001 \\
& Residual & 11704.776 & 39 & 300.122 & & \\
\cline { 2 - 5 } & Total & 18972.000 & 44 & & & \\
\hline
\end{tabular}

The table above reveals that the model represents banking transparency through Shariah and social disclosure. The model is statistically significant at $1 \%$ significance level.

Table 5 Coefficients

\begin{tabular}{|c|c|c|c|c|c|c|c|c|}
\hline & \multirow{2}{*}{ Model } & \multicolumn{2}{|c|}{$\begin{array}{l}\text { Unstandardized } \\
\text { Coefficients }\end{array}$} & \multirow{2}{*}{$\begin{array}{c}\text { Standardized } \\
\text { Coefficients } \\
\text { Beta }\end{array}$} & \multirow{2}{*}{$\mathrm{t}$} & \multirow{2}{*}{ Sig. } & \multicolumn{2}{|c|}{$\begin{array}{l}\text { Collinearity } \\
\text { Statistics }\end{array}$} \\
\hline & & B & $\begin{array}{c}\text { Std. } \\
\text { Error }\end{array}$ & & & & Tolerance & VIF \\
\hline \multirow{7}{*}{1} & (Constant) & 112.887 & 81.763 & & 1.381 & .175 & & \\
\hline & Power Distance & .011 & .580 & .007 & .019 & .985 & .102 & 9.848 \\
\hline & Individualism & -1.030 & .325 & -.518 & -3.165 & $.000^{*}$ & .591 & 1.692 \\
\hline & Uncertainty Avoidance & .090 & 391 & .057 & .229 & .820 & .258 & 3.874 \\
\hline & Moslem Population & -.394 & .509 & -.234 & -.773 & .444 & .173 & 5.775 \\
\hline & Masculinity & -2.860 & 1.397 & -.453 & -2.047 & $.048^{* *}$ & .298 & 3.353 \\
\hline & $\begin{array}{l}\text { Shariah Supervisory } \\
\text { Board }\end{array}$ & -.003 & 2.384 & .000 & -.001 & .999 & .383 & 2.610 \\
\hline
\end{tabular}

Dependent Variable: Social \&Shariah Disclosures

Note: ${ }^{*}$ significance at $10 \%,{ }^{* *}$ significance at $5 \%$

This study refers to Gray's hypothesis that a country with higher uncertainty avoidance and power distance and lower level of individualism and masculinity tends to have higher level of secrecy. The model reveals that only Individualism and Masculinity affect the disclosure practices. Other two cultural values namely Uncertainty Avoidance and Power Distance do not statistically influence the transparency level. The null hypothesis of this study states that there is no significant impact of cultural differences (uncertainty avoidance, power distance, individualism and masculinity) on transparency level (disclosure) in Islamic banks in different countries. The null hypothesis is partially accepted.

Other variables such as Moslem Population and the Shariah supervisory board do not have a significant effect of the disclosure practices in Islamic banks. This is due to all Islamic banks Shariah supervisory boards (Hashim, Mahadi, Amran, 2015; Rashid and Jabeen, 2016) and the board size is similar among Islamic banks. The bigger number of Moslems in a country is assumed to expect more transparent information. However, Moslem population does not have significant impact because all the 
countries examined are Moslem majority Countries having slightly same percentage of Moslem population.

\section{CONCLUSION}

Many studies have proven that cultural dimensions have a prevailing influence on human behaviours in some aspects including accounting and financial practices. Hofstede introduced cultural dimensions which became the reference of Gray's hypotheses on accounting value dimensions. This study attempts to examine one of Gray's hypotheses relating to transparency. Having the universal values and principles, Islamic banks are expected to provide the information (the same level of transparency). It is because religious values should surpass the cultural differences. This study finds that two out of four national cultures still have significant effect on the transparency level in Moslem majority countries. 


\section{REFERENCES}

Abbasi, T. H., Kausar, A., Ashiq, H., Inam, H., Nasar, H., Amjad, R. Corporate Social Responsibility Disclosure: A Comparison Between Islamic and Conventional Financial Institutions in Bahawalpur Region[J]. Journal of Financial Reporting and Accounting, 2012,3(3),51-61

[2] Ali, S. S., Hasan, H. Towards a Maqasid al-Shariah Based Development Index[C]. Islamic Research and Training Institute, 2014,18:1-22

[3] Anderson, C. W., Fedenia, M., Hirschey, M., Skiba, H. Cultural influences on home bias and international diversification by institutional investors. Journal of Banking and Finance, 2011,35(4):916934

[4] Aribi, Z. A., Gao, S. S. Narrative Disclosure of corporate Social Responsibility in Islamic Financial Institutions[J]. Managerial Auditing Journal, 2012,27(2):199-222

[5] Askary, S., Pounder, J. S., \& Yazdifar, H. Influence of Culture on Accounting Uniformity among Arabic Nations. Education[J]. Business and Society: Contemporary Middle Eastern Issues, 2008,1(2):145-154

[6] Asutay, M., Harningtyas, A. F. Developing Maqasid al- Shari ' ah Index to Evaluate Social Performance of Islamic Banks : A Conceptual and Empirical Attempt[J]. International Journal of Islamic Economics and Finance Studies, 2015,1(1):5-64.

[7] Boubakri, N., Mirzaei, A., Samet, A. National Culture and Bank Performance: Evidence from the Recent Financial Crisis[J]. Journal of Financial Stability, 2017,29:36-56

[8] Bukhari, K. S., Awan, H. M., Ahmed, F. An Evaluation of Corporate Governance Practices of Islamic Banks versus Islamic Bank Windows of Conventional Banks: A Case of Pakistan[J]. Management Research Review, 2013,36(4):400-416

[9] Chanchani, S., Willett, R. An Empirical Assessment of Gray's Accounting Value Constructs[J]. International Journal of Accounting, 2004,39(2):125-154

[10] Cooper, D. R., Schindler, P. S. Business Research Methods (11th editi)[M]. Singapore: McGraw Hill, 2011

[11] Dusuki, A. W. Understanding the Objectives of Islamic Banking: a Survey of Stakeholders ‘ Perspectives. International Journal of Islamic and Middle Eastern Finance and Management, 2008,1(2):132-148

[12] Gaygisiz, E. How Are Cultural Dimensions and Governance Quality Related to Socioeconomic Development?[J]. Journal of Socio-Economics, 2013,47:170-179

[13] Ghayad, R.Corporate Governance and the Global Performance of Islamic Banks[J]. Humanomics, 2008,24(3):207-216

[14] Gray, S. J. Towards a Theory of Cultural Influence on the Development of Accounting Systems Internationally[J]. Abacus, 1983:1-16

[15] Gray, S. J. Towards a Theory of Cultural-Influence on the Development of Accounting Systems Internationally[J]. Abacus, 1988,24(1):1-15 
[16] Haniffa, R., Hudaib, M. Exploring the Ethical Identity of Islamic Banks via Communication in Annual Reports[J]. Journal of Business Ethics, 2007,76(1),97-116

[17] Hashim, F., Mahadi, N. D., Amran, A. Corporate Governance and Sustainability Practices in Islamic Financial Institutions: The Role of Country of Origin[J]. Procedia Economics and Finance, 2015,31(15):36-43

[18] Hassan, A., Harahap, S. S. Exploring Corporate Social Responsibility Disclosure: The Case of Islamic Banks[J]. International Journal of Islamic and Middle Eastern Finance and Management, 2010,3(3):203-227

[19] Hofstede, G. Cultures and organizations: Software of the mind[J]. Great Britain: McGraw Hill, 1991

[20] Laitinen, E. K., \& Suvas, A. Financial Distress Prediction in an International Context: Moderating effects of Hofstede's Original Cultural Dimensions[J]. Journal of Behavioral and Experimental Finance, 2016,9,98-118

[21] Lu, Y., Abeysekera, I. Stakeholders' Power, Corporate Characteristics, and social and Environmental Disclosure: Evidence from China[J]. Journal of Cleaner Production, 2014,64:426-436

[22] Maali, B., Casson, P., Napier, C. Social Reporting by Islamic Banks[J]. Abacus, 2006,42(2):266289

[23] Nobanee, H., Ellili, N. Corporate sustainability disclosure in annual reports: Evidence from UAE banks: Islamic versus conventional[J]. Renewable and Sustainable Energy Reviews, 2016,55:1-6

[24] Rashid, A., Jabeen, S. Analyzing Performance Determinants: Conventional versus Islamic Banks in Pakistan[J]. Borsa Istanbul Review, 2016,16(2):92-107

[25] Rosly, S. A., Afandi, M., Bakar, A. Performance of Islamic and mainstream banks in Malaysia[J]. International Journal of Social Economics I, 2003,30(3):1249-1265

[26] Soana, M. The Relationship between Corporate Social Performance and Corporate Financial Performance in the Banking Sector[J]. Journal of Business Ethics, 2011,104,133-148

[27] Wan Ibrahim, W. H., Ismail, A. G. Conventional Bank and Islamic banking as Institutions : Similarities and Differences[J]. Humanomics, 2015,31(3):272-298

[28] Zarrouk, H., Jedidia, K. Ben, Moualhi, M. Is Islamic Bank Profitability Driven by Same Forces as Conventional banks?[J]. International Journal of Islamic and Middle Eastern Finance and Management, 2016,9(1):46-66 